A fentiek alapján úgy vélem, hogy egy igen sok információt tartalmazó jegyzetet bo- csátott a szerző az olvasók elé, amelyet hallgatóink és az érdeklödök haszonnal forgathatnak.

DR. ABONYINE DR. PALOTAS JOLÁN

\title{
SURYA KANT: ADMINISTRATIVE GEOGRAPHY OF INDIA
}

(India közigazgatási földrajza. Rawat Publications. Jaipur, 1988.280 p.)

A földrajztudomány nemzeti iskoláiban a legtöbb esetben visszatükrözódnek az adott ország legfontosabb problémái. A közigazgatási területszervezés földrajzi kérdéseinek kutatása és feltárása alapvető jelentőségű India számára.

A Panjab Egyetem Földrajzi Intézetében (Chandigork) egy nemzetközileg elismert és nagyra értékelt közigazgatás-földrajzi iskola alakult ki. Az intézet elsösorban az angol földrajz hagyományaira építette fel kutatási és oktatási tevékenységét. Posztgraduális jelleggel folyik a közigazgatás-földrajz oktatása, térszemlélettel rendelkezö közigazgatási szakemberek képzése. Ez volt az első ilyen jellegü központ Indiában.

Surya Kant a tér közigazgatási szervezésével kapcsolatos földrajzi kutatások fóbb irånyzatainak és eredményeinek bemutatásával indítja elemzését, s megállapítja, hogy a földrajztudomány - jelentős elméleti eredményei dacára - méltatlanul háttêrbe szorult a politikai és társadalmi térszerveződések kutatásában, pedig mind szemlélete, mind pedig módszertani apparátusa szinte erre a feladatra predesztinálja.

India történeti, területi, államszervezeti fejlödési folyamatának keretébe illesztve elsösorban Panjab (az öt folyó földje) kérdéscivel foglalkozik részletesen. Panjab ma India egyik legkisebb szövetségi állama, területe $50362 \mathrm{~km}^{2}$, lakossága 16,8 millió fő. Gazdaságilag India egyik lcgfejlettebb területe, az 1 före jutó nemzeti jövedelem meghaladja a 3560 rúpiát (kb. 300 dollár), $\mathrm{s}$ ez az egyik legmagasabb érték az indiai államok sorában. A településhálózata sokszinü, a városi népesség aránya $27,7 \%$, a településhálózaton belül meghatározó a 134 város, illetve városi agglomeráció, melyek a sû́rü faiuhálózat (12342 falu) igazgatási-ellátó központját képezik.

Panjab történcti, területi fejlődésẻt, a közigazgatási területbeosztás átalakulását i.c. 2750-tôl 1947.ig a hatalmi, a gazdasági, politikai, kulturális, vallási tényezők sokoldalú feltárásával taglalja a szerző. Bemutatja, hogy a mindenkori hatalom a saját felfogásának, érdekeinek, stratégiai szemiéletének és céljainak megfelelóen rendezkedett be, alakítottá át a terüiet közigazgatási struktúráját.

A mai folyamatok elốzményeként részletesen elemzi a szerző a történelmi Panjab kettéosztásának folyamatát. India függetlenné válásakor Panjab vallási alapon került felosztásra India és Pakisztán között. A történeti Panjab $359179 \mathrm{~km}^{2}$ terüle téból a gazdaságilag fejletlenebb $152649 \mathrm{~km}^{2} \mathrm{~K}$-i rész maradt India határain belül. A terület korábbi gazdasági és igazgatási központja - Lahore -- Pakisztánhoz került. 1956-ban a központi kormányzat úgy döntött, hogy India állami közigazgatási berendezkedését nyelvi alapokra kell helyezni. A területi reformot fokozatosan hajtották végre, Panjabra 1966-ban került sor. Ekkor leválasztották a fugget tlenség kivívásakor megmaradt területéról a hindu nyelvterületct. Az új államterület $\left(50362 \mathrm{~km}^{2}\right)$ mindössze $1 / 7$-e a történeti Panjab terüle tének.

A szerzô részletesen elemzi Panjab jelenlegi közigazgatási struktúráját, a különbözó jellegü és szintü közigazgatási egységek müködési mechanizmusát. Az 5 fokoza tú általános igazgatós, a speciális célokat szolgáló, változó hicrarchiájú szakigazgatés területi és müködési kérdéseinck széles körú elemzésc után a szerző matematikai statisztikai módszerekkel elemzi Panjab közigazgatási terülcti struktúráját, müködésének jogi és pénzügyi feltételeit, összetevőit, credményességét, és kúsérletet tesz egy optimális közigazgatási területbeosztás földrajzi alapjainak kimunkálására.

A magyar olvasó számára a monográfia i’galmas és hasznos olvasmány. ligy tölünk távoli ország, cltérö történeti, gazdasági, kulturális, politikai fejlölését érzékelve ismerhetjük meg India ćs különösen Panjab nagyon is hasonló közigazgatási területsecrvčećsi problémáit.

HAJDÚ ZOLTÁN 